\title{
Comparison of the springtime vertical export of biogenic matter in three northern Norwegian fjords
}

\author{
Marit Reigstad $^{1, *}$, Paul Wassmann ${ }^{1}$, Tatjana Ratkova ${ }^{2}$, Elena Arashkevich ${ }^{2}$, \\ Anna Pasternak ${ }^{2}$, Sigrid Øygarden ${ }^{1}$ \\ ${ }^{1}$ Norwegian College of Fishery Science, University of Tromsø, 9037 Tromsø, Norway \\ ${ }^{2}$ P. P. Shirshov Institute of Oceanology, Academy of Sciences of Russia, Nakhimovsky Avenue 36, 117581 Moscow, Russia
}

\begin{abstract}
A comparison of vertical flux of biogenic matter, phytoplankton and faecal pellets was carried out in April 1997 in 3 fjords, Ullsfjord, Balsfjord and Malangen, which exhibit different hydrographic conditions in the inner northern Norwegian coastal zone. Vertical export of biogenic matter was high (200 to $850 \mathrm{mg}$ particulate organoc carbon [POC] $\mathrm{m}^{-2} \mathrm{~d}^{-1}$ ) compared to previous years, particularly that of chlorophyll a (0.9 to $22 \mathrm{mg} \mathrm{m}^{-2} \mathrm{~d}^{-1}$ ). Some differences in the timing and composition between the fjords were detected, but on average, vertical export in the upper $100 \mathrm{~m}$ was similar in all three. Average phytoplankton carbon (PPC) sedimentation was $136 \mathrm{mg} \mathrm{C} \mathrm{m}^{-2} \mathrm{~d}^{-1}$, and it contributed $35 \pm 12 \%$ to the vertical export of POC. The diatoms Thalassiosira angulata, T. nordenskioeldii, Chaetoceros socialis and C. furcellatus were by far the most important taxa, contributing on average $68 \%$ to the PPC export. Another dominant spring bloom species in northern Norwegian fjords, the colony-forming prymnesiophyte Phaeocystis pouchetii, contributed on average only $12 \%$ to the vertical PPC flux, and it was of minor importance in Balsfjord. In contradiction to previous findings in the area, vertical POC export was not dominated by faecal pellet carbon (FPC) (125 $\mathrm{mg} \mathrm{C} \mathrm{m}^{-2}$ $\mathrm{d}^{-1}$ ). While a significant export of FPC and retention of PPC was observed during the vernal blooms in 1982, 1992 and 1996 ( $\mathrm{PPC} / \mathrm{FPC}=0.23 \pm 0.02)$, a mismatch scenario was encountered in $1997(\mathrm{PPC} /$ FPC $=1.32 \pm 0.31$ ), resulting in large-scale vertical export of diatoms. The differences in vertical export of biogenic matter between fjords were much smaller than interannual differences. It is suggested that interannual differences in oceanic-coastal coupling, crucial for the advection of mesoand macrozooplankton from the shelf adjacent to the fjords and for grazing, are the cause for the recurrent match and infrequent mismatch scenarios.
\end{abstract}

KEY WORDS: Vertical flux $\cdot$ Phytoplankton - Faecal pellets $\cdot$ Interannual variations $\cdot$ Northern Norwegian fjords

\section{INTRODUCTION}

In order to explain the variable efficiency of carbon channelled through the food web, Cushing (1975, 1990) hypothesised that the production of fish larvae was matched or mismatched to the production of their food. In more recent years the hypothesis has been expanded to the zooplankton-phytoplankton link (Fransz \& Gieskes 1984, Wassmann 1998). The consequences

*E-mail: maritr@nfh.uit.no of a zooplankton production matched or mismatched to the phytoplankton production are phytoplankton blooms with variable zooplankton grazing pressure. In case of a mismatch, large amounts of phytoplankton biomass can sink ungrazed and rapidly (aggregation) to the bottom of coastal seas. One cause for mesozooplankton mismatch could be their exclusion from overwintering in shallow areas as they require greater dephts. An important cause for match could be found in the advection of overwintering populations into the coastal zone in autumn, or advection of populations during spring. Match or mismatch is thus strongly influenced by the 
frequency and intensity of oceanic-coastal coupling across the shelf. We applied this extended matchmismatch hypothesis to investigate the dynamics of pelagic-benthic coupling.

Early investigations of pelagic-benthic coupling in coastal areas (e.g. Smetacek et al. 1984, Heiskanen \& Kononen 1994) supported the concept that the pelagic-benthic coupling reflected predominantly a mismatch scenario between phyto- and zooplankton in spring. Mismatches were also seen in west-Norwegian fjords (Wassmann 1991), which are characterised by shallow sills, high fresh-water run-off and variable degrees of permanent stratification. During recent years the shelf (Peinert 1986, Andreassen et al. 1999) as well as the fjords of northern Norway (Lutter et al. 1989, Riebesell et al. 1995, Keck \& Wassmann 1996, Reigstad \& Wassmann 1996, M.R. et al. unpubl.) have been investigated in greater detail with regard to pelagic-benthic coupling and its regulation. In the northern fjords, the sills are usually deep and freshwater run-off is often modest, highly seasonal and confined to the major run-off period lasting from late May to early autumn. Stratification is often negligible during spring, and this gives rise to significant mixing due to strong, topographically driven down-fjord winds (Svendsen 1995, Wassmann et al. 1996). Thus the spring bloom takes place in very weakly stratified waters, and it may be prolonged by frequent overturns of the upper layers (Eilertsen 1993, Hegseth et al. 1995).

The vertical export of biogenic matter, phytoplankton and faecal pellets has previously been investigated in Balsfjord (Lutter et al. 1989, Riebesell et al. 1995, Reigstad \& Wassmann 1996, M.R. et al. unpubl., Wexels Riser et al. unpubl.). These investigations revealed that vertical export during spring is considerable. It has been suggested that the level of vernal vertical export of biogenic material and its composition is strongly influenced by meso- and macrozooplankton, which either overwinter in the fjords or, more often, are advected into them during spring along with denser water masses from the open coastal zone (Falkenhaug et al. 1995, Reigstad \& Wassmann 1996). As a consequence, vertical export in spring is often dominated by meso- and macrozooplankton faecal pellets or detritus (e.g. Lutter et al. 1989, Riebesell et al. 1995,
Wexels Riser et al. unpubl.). These investigations support the general view that the vertical flux of biogenic matter in northern Norwegian fjords reflects a match rather than a mismatch between phyto- and zooplankton development, i.e. the vertical flux is generally dominated by faecal pellets and detritus, not by phytoplankton cells.

A detailed comparison of simultaneous vertical exports between several fjords has so far not been carried out in northern Norway. We asked the following questions: Is the magnitude and the composition of spring biogenic vertical export similar in different fjords? Does the timing of vertical export differ? Is faecal matter dominant in sedimenting material during spring in all fjords? In addition to these general questions, attention was given to the role of dominating phytoplankton taxa during the vernal bloom, i.e. diatoms and the prymnesiophyte Phaeocystis pouchetii. In order to address this set of questions, a quasi-simultaneous investigation of vertical export of biogenic matter, and especially phytoplankton and faecal pellets, was conducted in 3 hydrographically different fjords characterising the inner coastal zone of Troms county in northern Norway (Fig. 1).

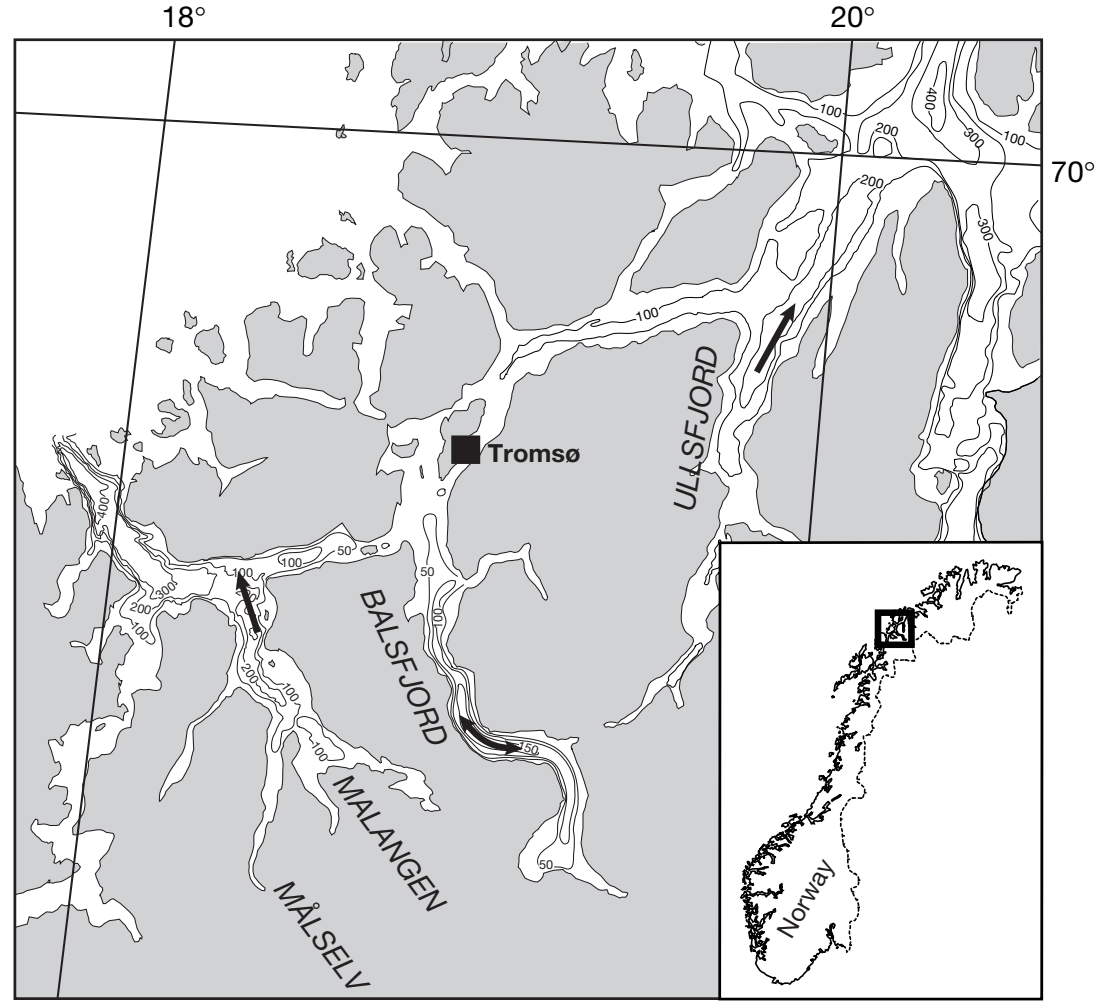

Fig. 1. The investigation area with the 3 largest fjords, Ullsfjord, Balsfjord and Malangen, close to the city of Tromsø, northern Norway. Also shown are the principle trajectories of the sediment trap mooring lines and the dominating river in the region, Målselv 


\section{MATERIAL AND METHODS}

Three centrally placed investigation sites were selected in Ullsfjord, Balsfjord and Malangen (Fig. 1). Malangen is directed north-westerly and has a deep, but narrow connection to the shelf. Ullsfjord is a funnel-shaped fjord, which is open to the shelf in a northerly direction. Both fjords are wide and have deep sills. Balsfjord is a narrow, winding fjord, which is separated from the more open fjords Malangen and Ullsfjord by 3 narrows which are 10 and $35 \mathrm{~m}$ deep (straits to the south and around the Island of Tromsø). The stations were visited 5 times on board the RV 'Johan Ruud' over a period of $18 \mathrm{~d}$, between April 8 and 24,1997 . An attempt was made to visit each station every third day, but bad weather after April 16 resulted in a slightly changed schedule. Each station was visited for about $18 \mathrm{~h}$, generally between 14:00 and 07:00 h the following day.

A drifter equipped with 4 sediment traps at 40,60 , 100 and $160 \mathrm{~m}$ was used. The sediment traps (KC maskiner og laboratorieudstyr, Denmark) were parallel cylinders mounted in a gimballed frame equipped with a vane to ensure that the cylinders were always positioned vertically and never shaded each other. The traps were $0.072 \mathrm{~m}$ in diameter and $0.45 \mathrm{~m}$ high (height/diameter ratio $=6.25$ ). They were deployed for about $17 \mathrm{~h}$ and no poison was used during the deployment. Therefore some grazing and bacterial decomposition might have taken place in the sediment traps during exposure.

The drifter was deployed 5 times at approximately the same position in each fjord (Fig. 1). Precautions regarding the start position had to be taken during periods of strong winds, which gave rise to a downfjord drift of the mooring, in particular in Malangen and Ullsfjord (Fig. 1). The mooring in Malangen stranded after about $10 \mathrm{~h}$ on April 14, and for the rest of the period no traps below $100 \mathrm{~m}$ depth were deployed in this fjord. The ship followed the drifter, taking CTDprofiles (Neil Brown Mk III CTD-profiler) 4 times during the sojourn. A failure of the CTD profiler between April 21 and 23 resulted in no available CTD profiles during Cruises 4 and 5 in Malangen and Cruise 4 in Ullsfjord.

After recovery, the contents of the sediment traps were transferred to bottles and kept cold $\left(<4^{\circ} \mathrm{C}\right)$ and dark. Samples were never kept more than $5 \mathrm{~h}$ before subsampling. Each sample was thoroughly mixed and a bird pipette was used for subsampling. Triplicate samples (200 to $300 \mathrm{ml}$ ) from each depth were taken and filtered for analysis of particulate organic carbon and nitrogen (POC and PON), chlorophyll $a(\mathrm{chl} a$ ) and phaeopigments on precombusted Whatman GF/F filters. Five replicate samples (50 to $100 \mathrm{ml}$ ) for the analy- sis of transparent exopolymer particles (TEP) were filtered upon polycarbonate filters $(0.4 \mu \mathrm{m}$ pore size $)$, stained with alcian blue according to Passow et al. (1994). The samples were kept frozen until analysis. Infrequently appearing swimmers were removed by means of forceps on all filters. Samples for microscopic examination of phytoplankton and faecal pellets were taken from all depths and fixed with a glutaraldehydeLugol solution (Rousseau et al. 1990).

Samples for chl $a$ and phaeopigments were analysed using a Turner Design AU-10 fluorometer according to Holm-Hansen et al. (1965). The fluorometer was calibrated for chl a (Sigma C6144), but other chlorophylls, mainly chl $C$, could also have been included in the results. POC and PON samples were analysed on a Leeman Lab CEC 440 CHN analyser after removal of carbonate with fumes of concentrated $\mathrm{HCl}$. TEP was analysed spectrophotometrically according to Passow \& Alldredge (1995).

Phytoplankton was counted with a non-inverted light microscope furnished with a counting stage (Semina 1978). Three different size classes were counted in 3 steps, using the appropriate sample volume and magnification, as described by Ratkova et al. (1999). The volume of algal cells was calculated using the appropriate stereometric formula (Smayda 1978). The average cell volume of each group was used to calculate the carbon content of the cells according to Strathmann (1967). No attempt was made to distinguish between heterotrophic and autotrophic cells. Thus, estimates of dinoflagellate and flagellate abundance and carbon content, and thereby the total phytoplanton carbon (PPC), may include mixotrophic and heterotrophic cells.

Sedimented faecal pellets were enumerated according to their shape and potential origin: (1) small spherical and ellipsoid faecal pellets originated from nauplii, (2) cylindrical faecal pellets from copepods, (3) strings from euphausiids, and (4) ellipsoid faecal pellets from appendicularians (E. Arashkevich pers. comm.). The first category was enumerated with a non-inverted light microscope furnished with a counting stage (Semina 1978). Large-sized faecal pellets were counted using a dissecting microscope in a total of $100 \mathrm{ml}$ sample. The length and width of the pellets were measured and the faecal pellet volume (FPV) calculated using appropriate stereometrical configurations according to Edler (1979). Each of these categories was separated into different size classes. Both intact and fragmented faecal pellets were counted. Due to difficulties of identification, small, broken or destroyed faeces may not have been taken into account.

To calculate the faecal pellet carbon (FPC) for a combination of all faecal pellet types, intact and fragmented pellets, the total FPV and an average POC/FPV 
ratio of $0.0691( \pm 0.0261) \mathrm{mg} \mathrm{C} \mathrm{mm}^{-3}$ was applied. This ratio was derived from 11 experiments, where $\mathrm{POC} /$ FPV ratios of 54 to 172 faecal pellets were determined 8 times for faecal pellets of Calanus finmarchicus, twice for Thyssanoessa spp. and once for appendicularians (E. Arashkevich unpubl. results).

\section{RESULTS}

\section{Hydrography}

Although some variation was recorded (e.g. April 8 in Malangen, April 12 in Balsfjord and April 10 and 16 in Ullsfjord), the differences in temperature, salinity and density indicated no major exchange of water masses throughout the sojourns and along the drift pathway. The recorded variability during the sojourns was not correlated to the tides. Temperature differences within the 3 fjords were small (Fig. 2A). Malangen was warmest $\left(3\right.$ to $4^{\circ} \mathrm{C}$ ) while Balsfjord was the coldest fjord $\left(1.6\right.$ to $\left.2.4^{\circ} \mathrm{C}\right)$. Also, salinity differences were small and no distinct pycnocline was present. Salinity was lowest in Balsfjord ranging between 33.5 and 33.75, and highest in Ullsfjord, ranging between 34.2 and 34.5 (Fig. 2B).
The homogeneity of the water column is illustrated by the difference and variability in $\sigma_{\mathrm{t}}$ between 170 and $0 \mathrm{~m}$, that was only $0.1032 \pm 5 \%$ and $0.1363 \pm 67 \%$ in Balsfjord and Ullsfjord, respectively. Due to the larger range of salinities in Malangen the difference was $0.4088 \pm 52 \%$. Throughout the investigated period there was a steady increase in salinity in Balsfjord (Fig. 2B), which indicates an inflow of more saline water. Inflow events of more saline water were not detected for the first 2 wk in Malangen, but in Ullsfjord an inflow of less saline water at intermediate depths was recorded at the end of the investigated period.

\section{Vertical export of particulate organic matter}

The vertical export of POC varied greatly between about 180 and $850 \mathrm{mg} \mathrm{m}^{-2} \mathrm{~d}^{-1}$ (Fig. 3). Vertical POC export generally increased with time and was relatively low until April 15 in the upper 100 m. In midApril, a windy period caused increased vertical POC export in Malangen, while a steady increase to the maximum vertical POC export was recorded in Balsfjord. The vertical POC export in Ullsfjord was less variable compared to Malangen and Balsfjord. At $160 \mathrm{~m}$
A)
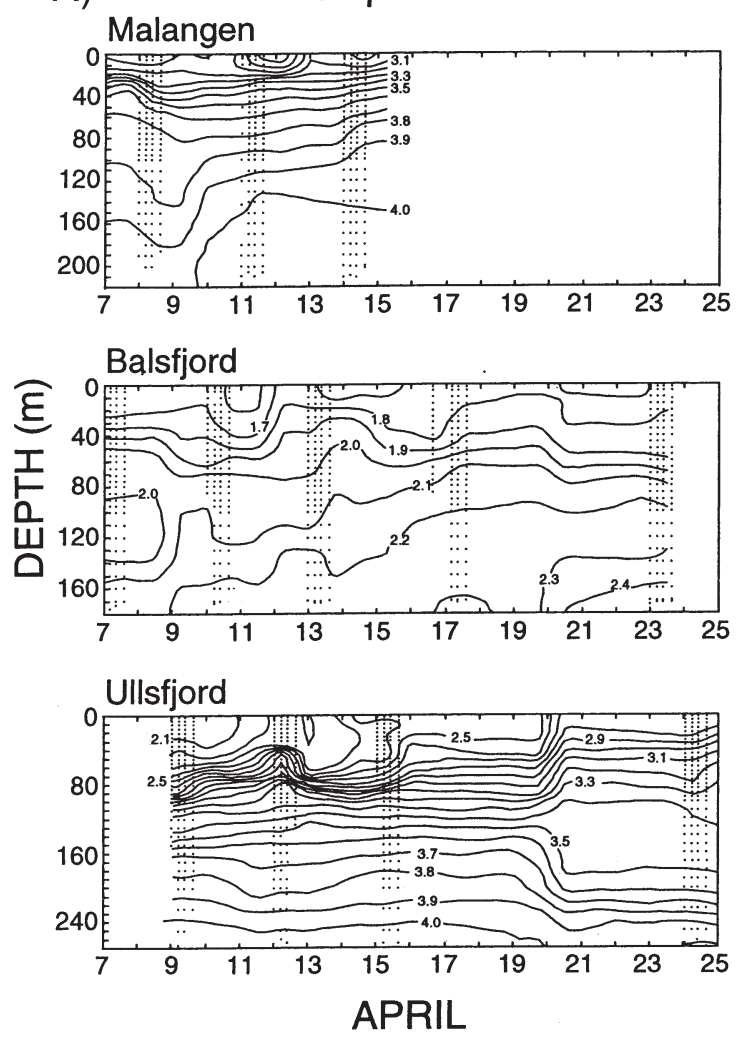

B) Salinity
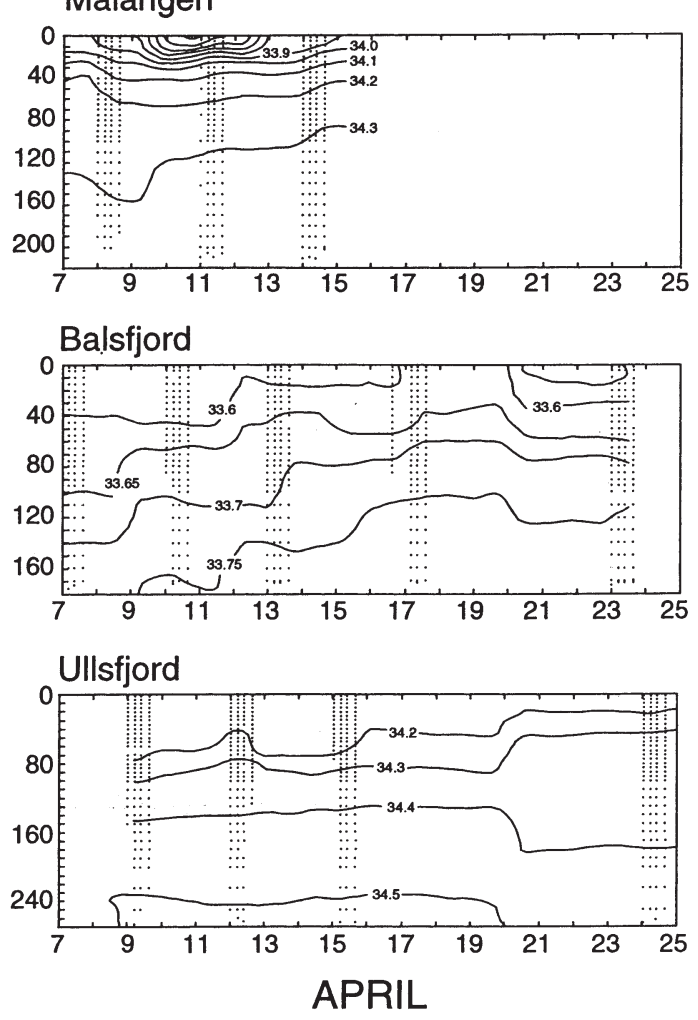

Fig. 2. (A) Temperature $\left({ }^{\circ} \mathrm{C}\right.$ ) and (B) salinity (PSU) along the trajectories in Malangen, Balsfjord and Ullsfjord from April 7 to 24 

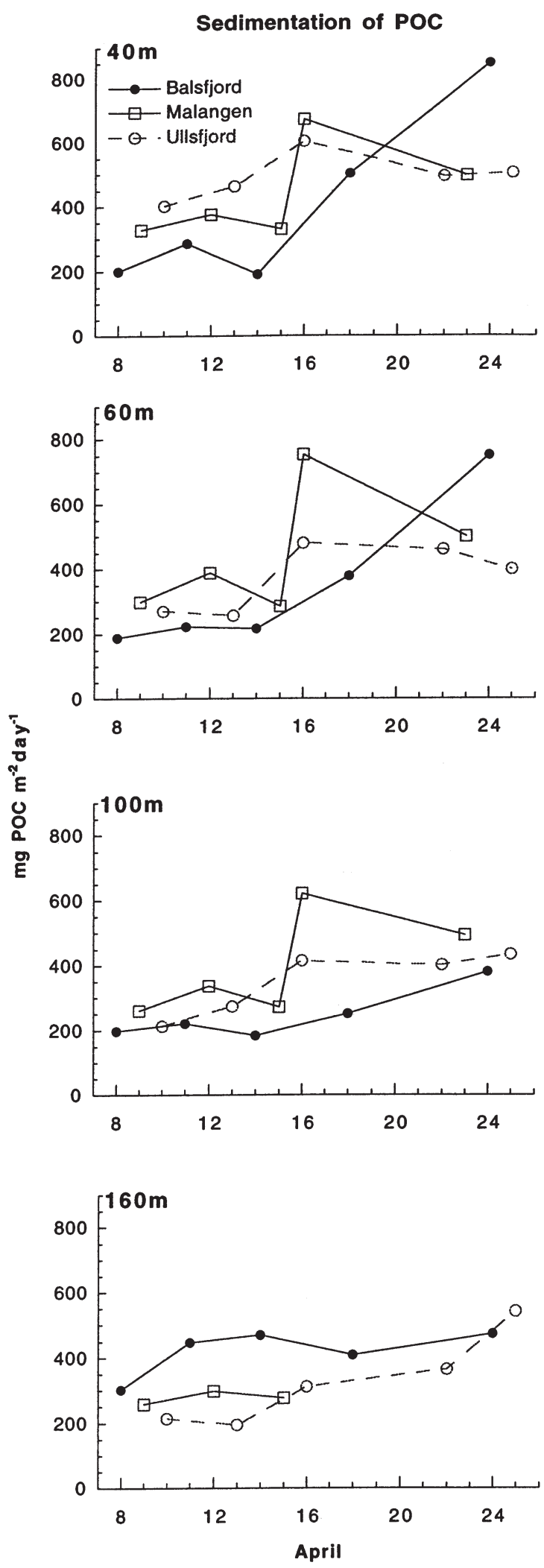

Fig. 3. Vertical export of particulate organic carbon (POC) in Balsfjord, Malangen and Ullsfjord at 40,60, 100 and $160 \mathrm{~m}$ depth in April $1997\left(\mathrm{mg} \mathrm{C} \mathrm{m}^{-2} \mathrm{~d}^{-1}\right)$ depth, vertical POC export varied little in all fjords, but a steady increase in POC export was recorded over time. While vertical POC export generally decreased with depth in Ullsfjord and Malangen, it increased significantly between 100 and $160 \mathrm{~m}$ in Balsfjord. This can be explained as resuspension from the sediment surface, which was higher at the station in the Balsfjord basin (Reigstad \& Wassmann 1996) compared to the deeper Malangen and Ullsfjord, where the trap was far above the sediment surface.

Patterns of vertical export of chl a were similar to those of POC in all fjords (Figs. 3 \& 4A), suggesting that much of the vertical POC export was due to phytoplankton. However, compared to POC the relative range of rates was greater for chl a (about 0.7 to $22 \mathrm{mg}$ $\mathrm{m}^{-2} \mathrm{~d}^{-1}$ ), and the decrease with depth was more significant. At 100 and $160 \mathrm{~m}$ depth vertical export of chl a ranged only between about 0.7 and 5 , with an average of $2.8 \mathrm{mg} \mathrm{m}^{-2} \mathrm{~d}^{-1}$. Noteworthy is the strong increase of vertical chl a export in Balsfjord after April 14 to surprisingly high rates of $22 \mathrm{mg} \mathrm{m}^{-2} \mathrm{~d}^{-1}$ at 40 and $60 \mathrm{~m}$ depth. Balsfjord also had the largest vertical export of chl a $\left(3.7 \mathrm{mg} \mathrm{m}^{-2} \mathrm{~d}^{-1}\right)$ at $160 \mathrm{~m}$ depth, while that in Ullsfjord and Malangen was $2 \mathrm{mg} \mathrm{m}^{-2} \mathrm{~d}^{-1}$, on average (Fig. 4A). High POC sedimentation rates in Malangen in mid-April were probably caused by wind-induced resuspension, and associated rather with high $\mathrm{C} / \mathrm{N}$ ratios than chl $a$.

Compared to POC and chl $a$, the vertical export of phaeopigments was less variable in the 3 fjords and ranged between 4 and $16 \mathrm{mg} \mathrm{m}^{-2} \mathrm{~d}^{-1}$ (data not shown). The vertical export of phaeopigments was generally greater in Ullsfjord and Malangen, suggesting that phaeopigment producing processes, such as grazing on phytoplankton, were of greater significance in these fjords than in Balsfjord. However, at $160 \mathrm{~m}$ depth Balsfjord had the greatest vertical phaeopigment export. The chl $a$ /phaeopigment ratio of the vertically exported matter at $40 \mathrm{~m}$ depth ranged widely between 0.1 and 4.3 in Balsfjord (Fig. 4B). Vertical export of biogenic matter was strongly dominated by fresh phytoplankton after April 14 at $40 \mathrm{~m}$ depth. This trend diminished at $60 \mathrm{~m}$ depth, where the maximum ratios declined to 1.8. Below $60 \mathrm{~m}$ depth all $\mathrm{chl}$ a/phaeopigment ratios were $<1$, ranging from 0.1 to 0.8 with an average of 0.31 . For Ullsfjord and Malangen the chl a/ phaeopigment ratio was generally $<1$, and the variation over time was rather limited. This implies that phaeopigment producing processes were capable of preventing the large-scale vertical export of fresh phytoplankton below $60 \mathrm{~m}$ in the fjords. The increase in phaeopigment export at $160 \mathrm{~m}$ in Balsfjord is interpreted as resuspension.

The POC/PON (a/a) ratio of the sedimenting material ranged widely between 7.2 and 11.6 (Fig. 5A). The 
A)
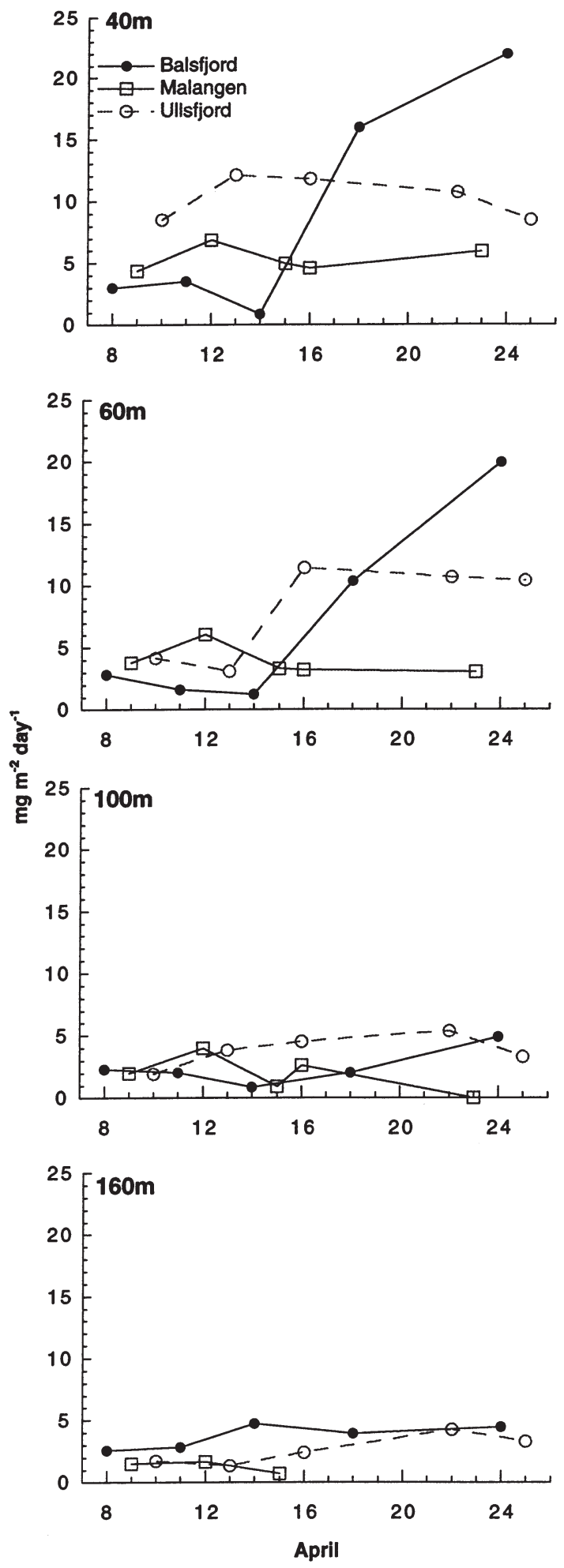

B)

Chl a/ Phaeopigment
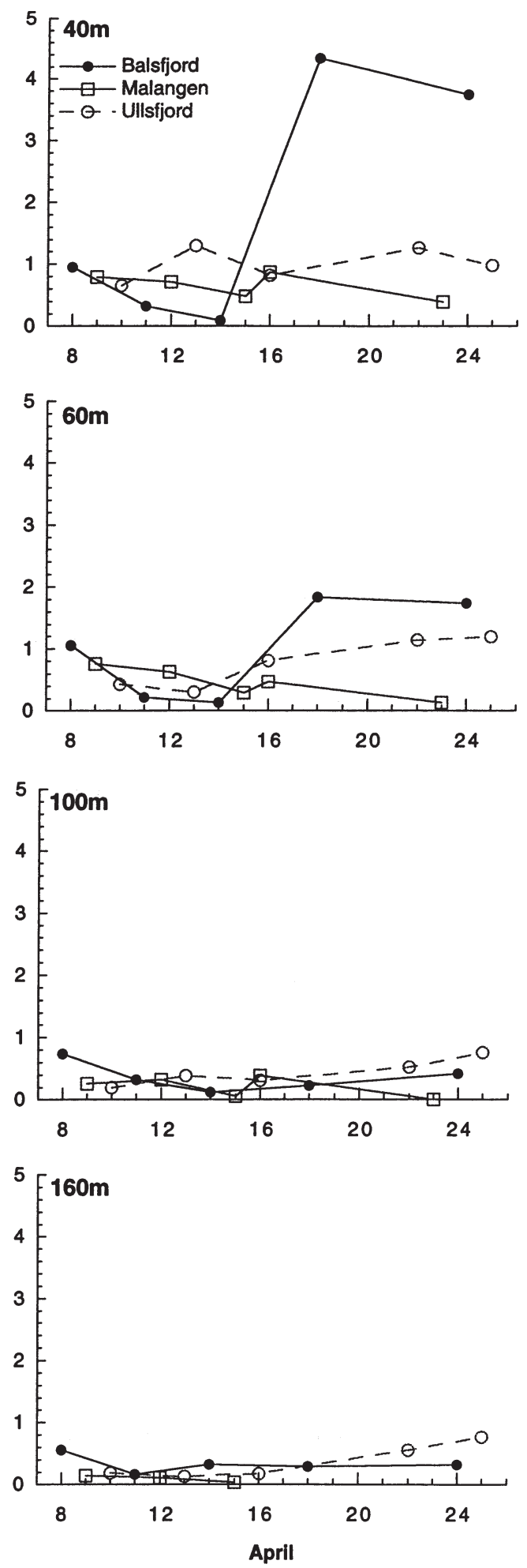

Fig. 4. Vertical export of (A) chl a $\left(\mathrm{mg} \mathrm{m}^{-2} \mathrm{~d}^{-1}\right)$ and (B) ratio of chl $a$ and phaeopigments (w/w) of the vertically exported matter in Balsfjord, Malangen and Ullsfjord at 40,60, 100 and $160 \mathrm{~m}$ depth in April 1997 
A)

POC/PON atomic ratio
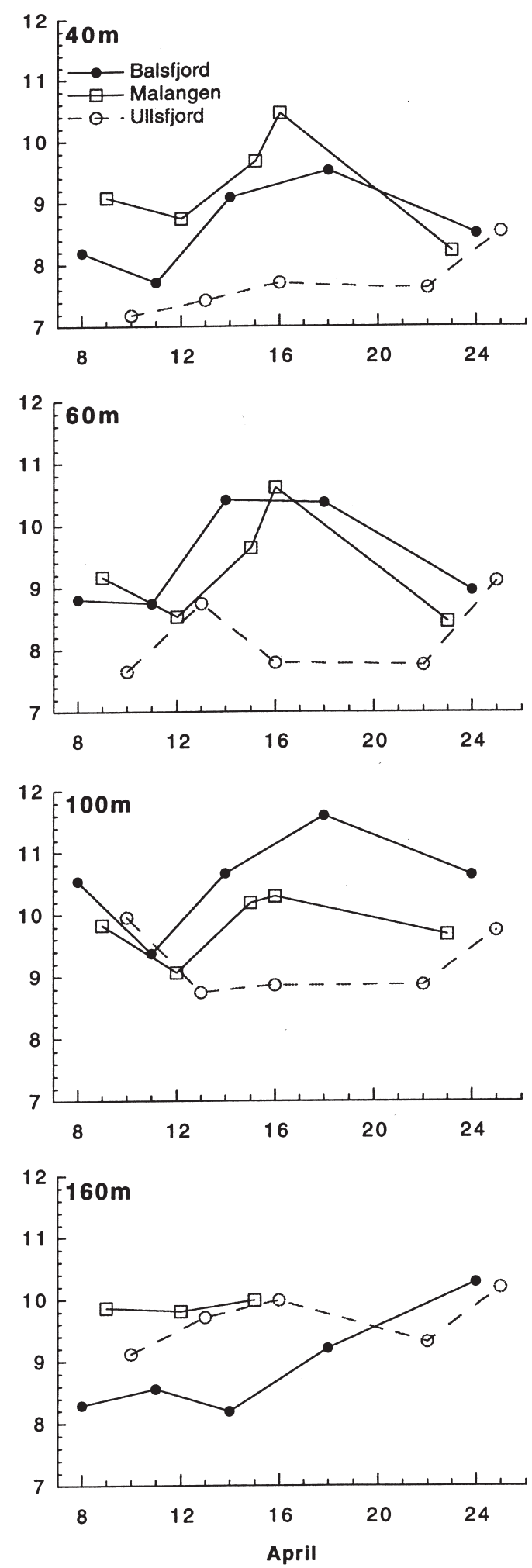

B)

Chl/ POC
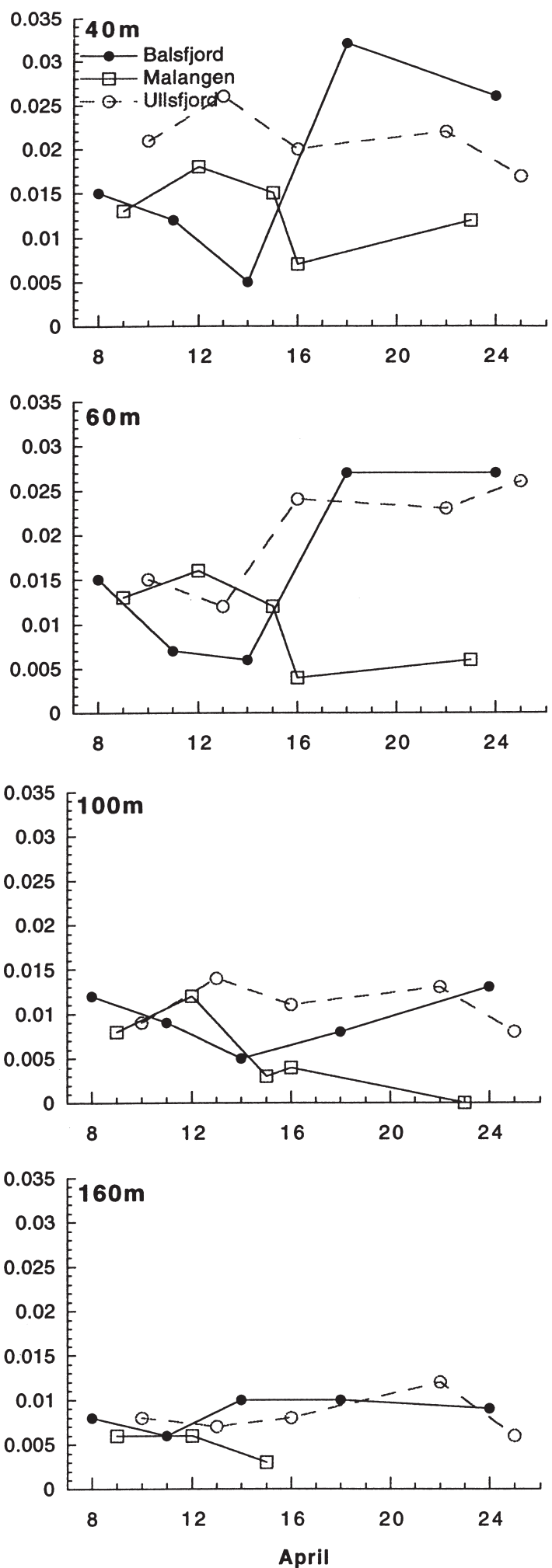

Fig. 5. Ratio of (A) POC and PON (a/a) and (B) chl a and POC (w/w) of the vertically exported matter in Balsfjord, Malangen and Ullsfjord at 40,60, 100 and $160 \mathrm{~m}$ depth in April 1997 
lowest POC/PON ratios were encountered in Ullsfjord in early April at $40 \mathrm{~m}$ depth. A maximum was recorded in the middle of April for both Balsfjord and Malangen, while the variability with time was smaller in Ullsfjord. There was a general increase in the POC/PON ratios with depth, except in Balsfjord, where ratios decreased at $160 \mathrm{~m}$ depth, perhaps because fresh material which settled in the more shallow areas of the fjord was resuspended and introduced to the basin water by advection along the fjord axis. The lowest ratios were encountered in Ullsfjord and the smallest vertical variability in Malangen. In Balsfjord the average POC/PON ratios increased distinctively in the upper $100 \mathrm{~m}$ from 8.6 at $40 \mathrm{~m}$ to 10.6 at $100 \mathrm{~m}$ depth, on average.

The chl $a / \mathrm{POC}$ ratios of the exported matter varied noticeably between the fjords at 40 and $60 \mathrm{~m}$ depth, while less variability was encountered at greater depth (Fig. 5B). The ratios suggest that more detritus was exported vertically from the upper layers in Balsfjord in the first part of April, but that fresh phytoplankton dominated from April 14 onwards. Up to $3.2 \%$ of the POC export was due to chl $a$. In Ullsfjord the chl a/POC ratios were less variable, but generally high in the upper $60 \mathrm{~m}$, and almost as high as in Balsfjord at $60 \mathrm{~m}$ depth in the latter part of April. In Malangen the chl a/ POC ratios were generally lower in the upper layer and decreased generally with time, implying that the vertically exported biogenic matter was more depleted of fresh phytoplankton.

The entire range of vertical TEP export rates in the fjords was small, 14 to $76 \mathrm{mg}$ xanthan equivalents $\mathrm{m}^{-2}$ $\mathrm{d}^{-1}$ (data not shown). The average TEP export rates (all depths and all dates) were highest in Ullsfjord, intermediate in Malangen and lowest in Balsfjord (47.9, 41.1 and $23.7 \mathrm{mg}$ xanthan equivalents $\mathrm{m}^{-2} \mathrm{~d}^{-1}$, respectively). Maxima were found in the upper $100 \mathrm{~m}$ on April 15 and 17 in Malangen, April 16 and 22 in Ullsfjord and April 24 in Balsfjord. While there was a general decrease in vertical TEP with depth in Ullsfjord and Malangen, a doubling or more in TEP flux was encountered between 100 and $160 \mathrm{~m}$ depth in Balsfjord.

\section{Vertical export of phytoplankton}

Comparison of the vertical export of total PPC (calculated from phytoplankton counts and probably including heterotrophic dinoflagellates and flagellates) (Fig. 6) with that of POC (Fig. 3) indicates that PPC export was of great significance in all 3 fjords during April 1997. The greatest vertical export was encountered in the latter part of the investigation period. Vertical export of PPC ranged between 35 and $340 \mathrm{mg} \mathrm{m}^{-2} \mathrm{~d}^{-1}$ and decreased, on average, slightly with depth, except for the $160 \mathrm{~m}$ depth trap in Balsfjord, where vertical
Total PPC flux
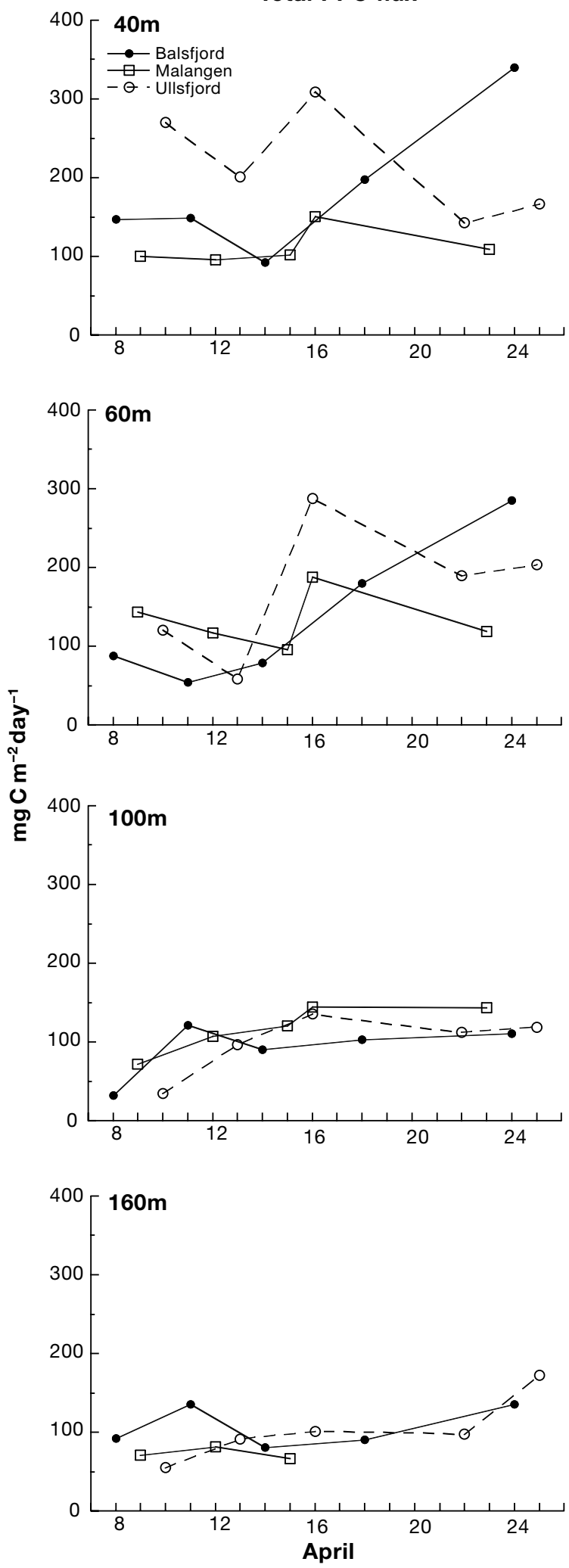

Fig. 6. Vertical export of total phytoplankton carbon (PPC) in Balsfjord, Malangen and Ullsfjord at 40,60, 100 and $160 \mathrm{~m}$ depth in April $1997\left(\mathrm{mg} \mathrm{C} \mathrm{m}^{-2} \mathrm{~d}^{-1}\right)$ 
PPC fluxes increased again. The variation with depth was variable and the average $\mathrm{PPC} / \mathrm{POC}$ ratios were similar in Ullsfjord and Balsfjord (0.37 and 0.39, respectively) but lower in Malangen (0.29). The high $\mathrm{PPC} / \mathrm{POC}$ ratios suggest that much of the spring bloom in these 3 fjords in April 1997 was vertically exported as ungrazed phytoplankton. The time variation of the vertical export of PPC was rather limited at 100 and $160 \mathrm{~m}$ depth. A comparison of the total vertical PPC export (Fig. 6) with that of diatom carbon (16 to $330 \mathrm{mg}$ $\mathrm{m}^{-2} \mathrm{~d}^{-1}$, Fig. 7A), reveals that the vertical export of PPC was dominated by diatoms. On average $73 \pm 4,74 \pm 7$ and $57 \pm 6 \%$ of the total vertical PPC export was due to diatoms in Balsfjord, Malangen and Ullsfjord, respectively, with other taxa playing a minor role only. For example, the vertical export of Phaeocystis pouchetii cells (free and colonial, Fig. 7B) was negligible in Balsfjord, rather low in Malangen and highest in Ullsfjord at all depths $(1.2,8.0$ and $25.3 \%$ of PPC export, respectively). The vertical export of $P$. pouchetii carbon was always lower than $95 \mathrm{mg} \mathrm{m}^{-2} \mathrm{~d}^{-1}$. By far the greatest number of $P$. pouchetii was cells derived from colonies and colony fragments rather than single cells. Thus $P$. pouchetii colonies sank to a greater depth, but their vertical flux declined strongly with increasing depth. On average, diatom and $P$. pouchetii cell carbon decreased by a factor of 1.9 and 2.6, respectively, between 40 and $100 \mathrm{~m}$ depth.

Among the diatoms, Chaetoceros furcellatus, C. socialis, Thalassiosira angulata and $T$. nordenskioeldii were by far the most important species with respect to carbon export. In Ullsfjord T. angulata was the most important species for the export of diatom carbon throughout the investigation. T. nordenskioeldii was the second most important, while C. socialis and C. furcellatus were least important among the 4 dominant diatoms species. Spores of $C$. socialis appeared from April 13 and onwards and increased over time. At the end of the investigation both C. furcellatus and T. nordenskioeldii contributed with spores to the vertical export. In Balsfjord T. angulata and T. nordenskioeldii dominated the vertical export of diatom carbon up to midApril, when C. socialis became increasingly important. However, C. socialis never displaced T. angulata as the most important diatom species in the sedimenting material. C. furcellatus was of minor significance. Spores were first recorded on April 14 for C. socialis, but showed a maximum on April 24, when C. furcellatus and $T$. nordenskioeldii also contributed to spore export in Balsfjord. At the end of April, C. socialis spores were more prominent than their vegetative cells. In Malangen, $T$. angulata dominated the vertical export of diatom carbon on April 9, followed by T. nordenskioeldii on April 12 and C. socialis on April 15. By the end of the investigation period, $T$. angulata and T. nordenskioeldii dominated again. However, the diatom composition was less variable among the 4 major species compared to Ullsfjord and Balsfjord. C. socialis spores were encountered in the traps from April 12 and onwards. On April 15 C. furcellatus spores appeared, and finally $T$. nordenskioeldii spores were encountered on April 23.

Diatoms and Phaeocystis pouchetii cells comprised together on average $68 \%$ of the total vertical PPC export. Other phytoplankton species did not contribute greatly. Only dinoflagellates and flagellates were of some significance, while coccolithophorids and silicoflagellates were only occasionally encountered among the 117 identified phytoplankton species. In addition, larger protozoa did not contribute much to the export of organic matter (2 to $20 \mathrm{mg} \mathrm{C} \mathrm{m}{ }^{-2} \mathrm{~d}^{-1}$ ). They were more abundant in Balsfjord than in Malangen and Ullsfjord. Radiolaria dominated among the larger protozoan plankton in Balsfjord; tintinnids were more abundant in Malangen and Strobilidiidae in Ullsfjord. Radiolaria and tintinnids were most abundant in the 100 and $160 \mathrm{~m}$ traps.

\section{Vertical export of faecal pellets}

The average vertical export of FPC was often lower than PPC at 40 and $60 \mathrm{~m}$ depth (Figs. 6 \& 8). Except for 1 peak in Balsfjord and a strong increase at depth in Malangen, the rates were generally $<200 \mathrm{mg} \mathrm{C} \mathrm{m}^{-2} \mathrm{~d}^{-1}$. FPC vertical export increased slightly with time, starting from rates $<50 \mathrm{mg} \mathrm{C} \mathrm{m}^{-2} \mathrm{~d}^{-1}$ in early April, except for the bottom waters of Balsfjord, which generally had higher FPC vertical flux rates. Except for the FPC vertical export in the bottom water, and near the end of the investigated period, Balsfjord generally had the lowest rates, while Malangen had the highest from April 12 onwards. High vertical FPC export was recorded at $100 \mathrm{~m}$ depth in Malangen from April 15. FPC/POC ratios ranged on average between 18 and $53 \%$. Average FPC/POC ratios increased with depth: $20,25,40$ and $44 \%$ at $40,60,100$ and $160 \mathrm{~m}$ depth, respectively, implying that faecal pellets contributed increasingly to the vertical POC export. Sinking faecal pellets originated mainly from larger copepods (primarily Calanus finmarchicus) and euphausiids (Thyssanoessa spp.). Slight distinctions in proportion of the various faecal pellet categories were found in different fjords. In Balsfjord the export of carbon enclosed in euphausiid faecal pellets comprised more than $50 \%$, sometimes up to $85 \%$, of the total FPC export. In Malangen the vertical flux was dominated by faecal pellets most likely originating from $C$. finmarchicus during the first 3 cruises, while during the last 2, the contribution of euphausiid faecal pellets increased up to $60-70 \%$ at the depth of $\geq 100 \mathrm{~m}$. In Ullsfjord the pro- 
A)
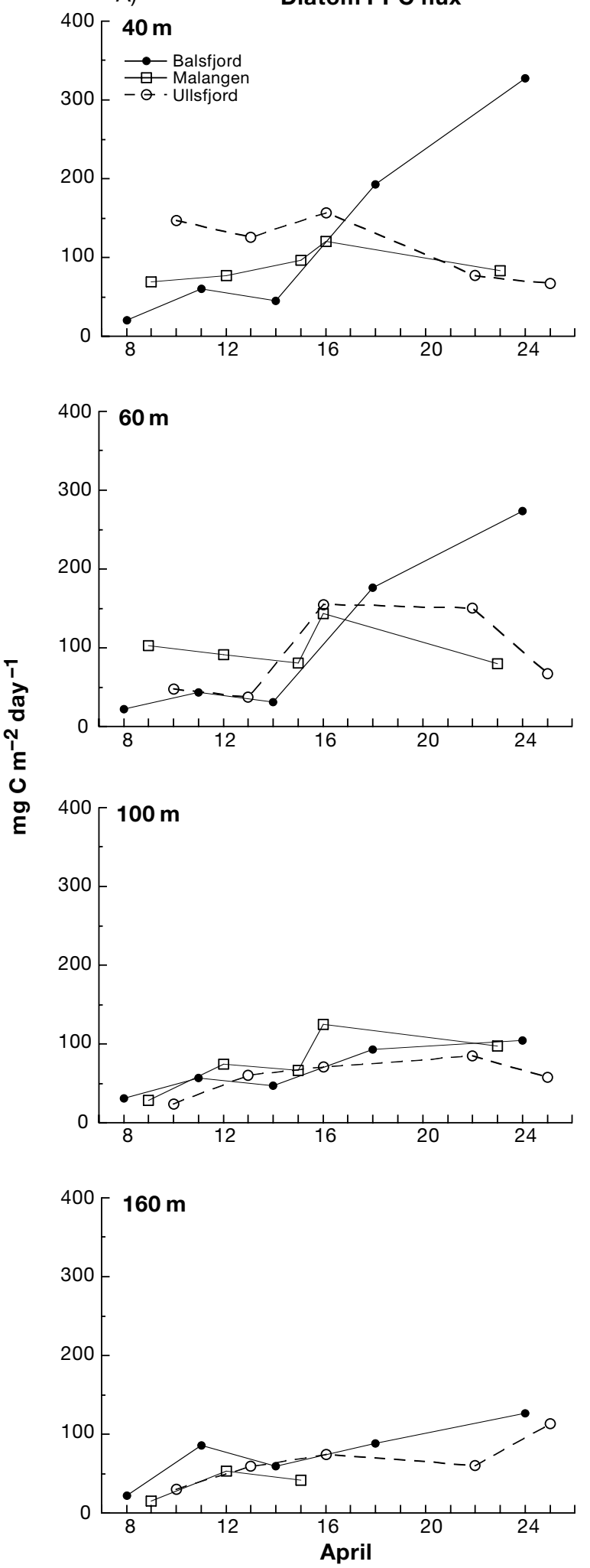

B)
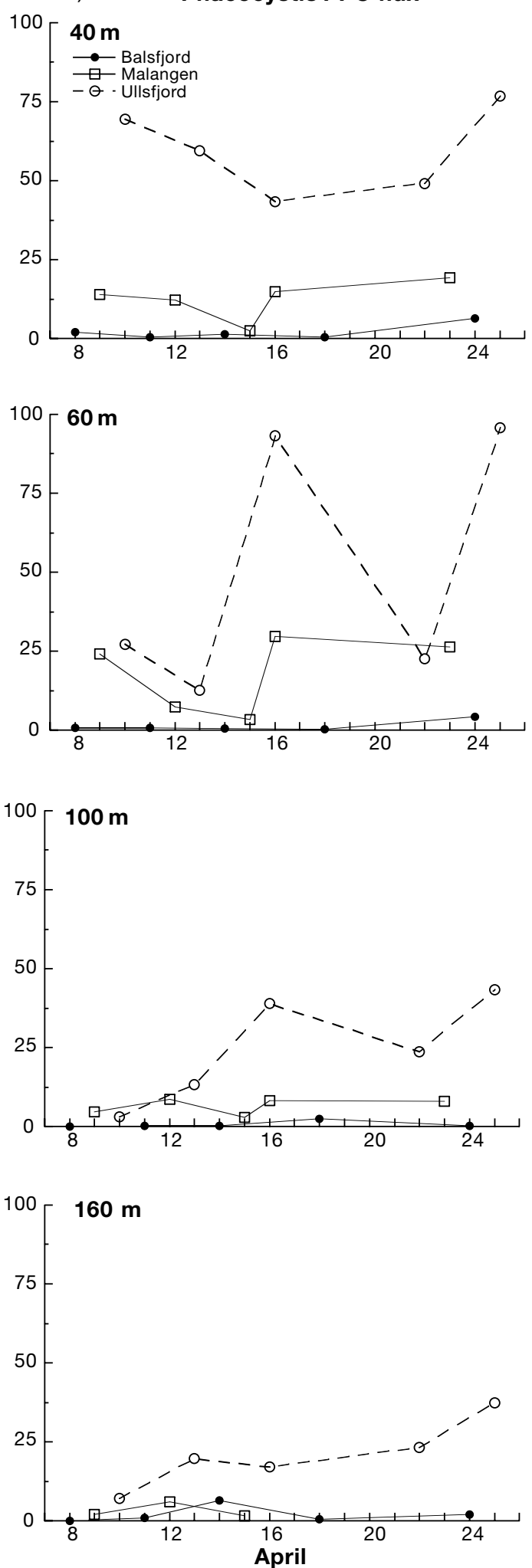

Fig. 7. Vertical export of (A) diatom PPC and (B) Phaeocystis pouchetii (total cell numbers) PPC in Balsfjord, Malangen and Ullsfjord at 40,60, 100 and $160 \mathrm{~m}$ depth in April $1997\left(\mathrm{mg} \mathrm{C} \mathrm{m}^{-2} \mathrm{~d}^{-1}\right)$ 
FPC
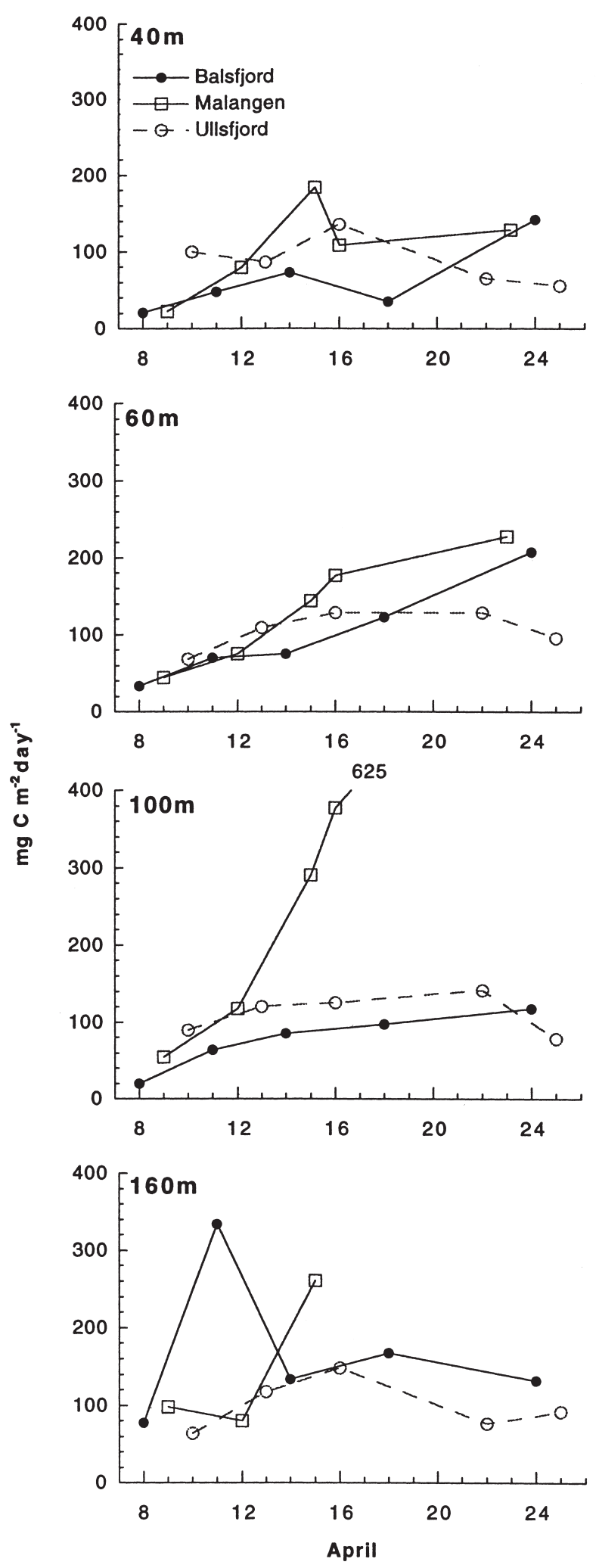

Fig. 8. Vertical export of faecal pellet carbon (FPC) in Balsfjord, Malangen and Ullsfjord at 40,60, 100 and $160 \mathrm{~m}$ depth in April 1997 (mg C m$\left.{ }^{-2} \mathrm{~d}^{-1}\right)$ portion of faecal pellets from C. finmarchicus and euphausiids was equal.

The contribution of small round/oval faecal pellets from crustacean nauplii to the FPC export varied with time. At the beginning of the investigation they comprised only 1 to $5 \%$ of the FPC flux, but by the end of April their contribution to the FPC export increased up to $30-50 \%$. Faecal pellets originating from appendicularians played a minor role, contributing less than $1 \%$ of the total carbon export, with the exception of the last 2 stations in Malangen (12 to $15 \%$ of the total FPC flux).

\section{DISCUSSION}

The first comparative investigation of vertical export in northern Norwegian fjords (Malangen and Balsfjord) was conducted in 1992 (Reigstad \& Wassmann 1996). The fjords revealed strong similarities with respect to the magnitude and timing of total vertical export in spring and early summer despite differences in sill depth, and distance and exposure to the open coast (Fig. 1). Based on this investigation, Reigstad \& Wassmann (1996) suggested that annual differences in vertical flux of organic matter between adjacent fjords may be small, but that interannual differences may be more prominent. It was proposed that large-scale variations in meteorological forcing along the coast, the advection of shelf water into adjacent fjords (Svendsen 1995) and the concomitant advection of nutrients, phytoplankton and zooplankton (e.g. Aksnes et al. 1989, Falkenhaug et al. 1995) had a more significant influence on the vertical flux in the fjords than topography and sill depth. The present investigation enables us to explore this suggestion in greater detail by comparing events in 3 fjords simultaneously for the major time window of the vernal bloom. Furthermore, the previous investigations in Balsfjord in 1982 (Lutter et al. 1989), 1992 (Riebesell et al. 1995, Reigstad \& Wassmann 1996), and 1996 (M.R. et al. unpubl.) provide the data for an interannual comparison of vernal blooms and concomitant pelagic-benthic coupling. The question was if our investigation supports the hypothesis that interannual variations in the vertical export of biogenic matter are greater than the differences between fjords.

\section{A 'classical' spring bloom: moderate grazing and high vertical export of diatoms}

The most prominent result of the present investigation was the high vertical export of PPC, and in particular diatoms, in the 3 fjords. It is commonly believed that vernal blooms in boreal, coastal waters are char- 
acterised by the proliferation of large phytoplankton taxa and a large-scale export of chains, single cells and aggregates (e.g. Smetacek et al. 1984, Kiørboe et al. 1994, Passow et al. 1994). A 'classical' vernal bloom suggests an imbalance between the production of large cells (generally diatoms) and their pelagic utilisation resulting from the limited grazing impact of larger zooplankton species, which do not overwinter in high abundance at shallow depths (Heiskanen 1998, Wassmann 1998). The spring bloom in the 3 northern Norwegian fjords in 1997 showed this 'classical' pattern. There was a significant accumulation of diatoms (T. N. Ratkova pers. comm.) and vertical export of $\mathrm{chl} a$, and diatom PPC (Figs. 4A \& 7A) was several times higher compared to levels found in previous investigations (e.g. Lutter et al. 1989, Riebesell et al. 1995, M.R. et al. unpubl.), and the grazing impact due to large zooplankton was apparently limited, since FPC export was moderate (Fig. 8). Thus, in spring 1997 the food web in the near surface layers was not 'retentive' since it could not increase recycling of phytoplankton sufficiently to limit the export of fresh and ungrazed cells.

The fact that microzooplankton could have played an important role as selective grazers favouring the growth of large-celled phytoplankton has also been considered. However, the concentration of microzooplankton (mainly ciliates) was very low in all 3 fjords (mostly below $1 \mathrm{mg} \mathrm{C} \mathrm{m}^{-2}$ ) in 1997, and in Balsfjord in 1996, in spite of high concentrations of available food both years (T.R. \& M.R. unpubl. data). A recent investigation on the adjacent northern Norwegian shelf revealed a scenario in which Verity et al. (1999) concluded that despite high production being seen as a significant nutrient consumption of silicate and nitrate, large-celled phyto- and microzooplankton biomasses were low due to high grazing pressure from mesozooplankton. Even if our investigation in spring 1997 showed fjord ecosystems with apparently reduced grazing pressure from mesozooplankton compared to earlier years, the microzooplankton growth was not able to keep up with the loss rates, resulting in low biomass. The microzooplankton thus seemed to be low during both the match and mismatch scenarios investigated, implying that microzooplankton biomass is probably grazer controlled at lower mesozooplankton concentrations compared to large-celled phytoplankton. Without specific grazing experiments, their role as consumers is hard to evaluate, but the impact from microzooplankton on the carbon flow and phytoplankton community structure seems to have been limited by meso- and macrozooplankton grazing to a greater extent than the large-celled phytoplankton growth.

If the results of the 1997 investigation had been the first collected in this area, one might have concluded that northern Norwegian fjords function similarly to other shallow coastal ecosystems with a significant sedimentation of diatoms (e.g. Smetacek et al. 1984, Laws et al. 1988, Wassmann 1991, Heiskanen 1998). However, it was only in 1997 that the fjords behaved in the 'classical' manner: a large export of POC, chl $a$, $\mathrm{PPC}$ and low $\mathrm{C} / \mathrm{N}$ and high chl a/POC ratios. In northern Norwegian fjords, all investigations during previous years revealed very different scenarios in which: (1) suspended phytoplankton biomass in the upper layers was variable (often low) and not necessarily dominated by diatoms, but frequently by colonies of the prymnesiophyte Phaeocystis pouchetii (Lutter et al. 1989, Riebesell et al. 1995, M.R. et al. unpubl.); (2) the vertical flux of biogenic matter was moderate and often dominated by FPC, while the chl a export was low (Reigstad \& Wassmann 1996); (3) among the recognisable particles, faecal pellets dominated and FPC often comprised $80 \%$ or more of the vertical POC flux, while the export of PPC contributed to a minor fraction $(<24 \%$ ) (Riebesell et al. 1995, M.R. et al. unpubl., Wexels Riser et al. unpubl.). Retentive food webs were thus well developed during the spring bloom in 3 out of 4 years.

If the 4 vernal blooms investigated so far are representative of the interannual variability in northern Norwegian fjords, it is tempting to suggest that the situation in 1997 was anomalous. If this is so, then in general, meso- and macrozooplankton (overwintered and/ or advected) govern vernal bloom development and its vertical export in northern Norwegian fjords, i.e. the vertical coupling is generally under 'top-down' grazing control. The number of large-sized grazers probably depends on the oceanic-coastal coupling, i.e. the frequency, timing and duration of meteorologically induced advective episodes, particularly during late winter and spring (Svendsen 1995). If large numbers of grazers are introduced prior to the bloom, they can limit the accumulation of large-celled phytoplankton blooms and create scenarios in which the faecal pellet production is high and detrital matter is almost instantaneously exported in large quantities to the bottom water and the sediment in faecal pellets, aggregates or detritus. That was clearly the case during spring 1996 when vertical export of FPC dominated vertical carbon export in Balsfjord (M.R. et al. unpubl., Wexels Riser et al. unpubl.). Our data imply that interannual variability is crucial for an in-depth understanding of carbon cycling in the northern Norwegian coastal zone. Four vernal investigations are obviously not sufficient to determine the annual frequency of match and mismatch scenarios. It may well be that a pattern of high and moderate vertical export of PPC and FPC, respectively, is more common than has been recorded so far (see Fig. 9). Time series data regarding the advection of shelf water, phyto- and zooplankton composition 
and standing stock are unfortunately not available to provide a qualitative understanding of the frequency of match and mismatch scenarios in northern Norwegian fjords.

\section{Export and retention of diatoms and Phaeocystis pouchetii during match and mismatch scenarios}

Among the larger phytoplankton taxa prevailing during the vernal bloom are both diatoms and Phaeocystis pouchetii. Differences in the spring bloom composition have been reported, ranging between years of diatom or P. pouchetii dominance (H. C. Eilertsen pers. comm.). The reason for this variability is not evident, and interannual variability in resuspension of diatom spores (Eilertsen et al. 1995, Wassmann et al. in press), lateral advection of seeding populations from the shelf (e.g. Braarud 1975, Erga \& Heimdal 1984) or selective grazing by meso- and macrozooplankton are among the options. The contribution of $P$. pouchetii to the vertical carbon export is also a matter of controversy (e.g.

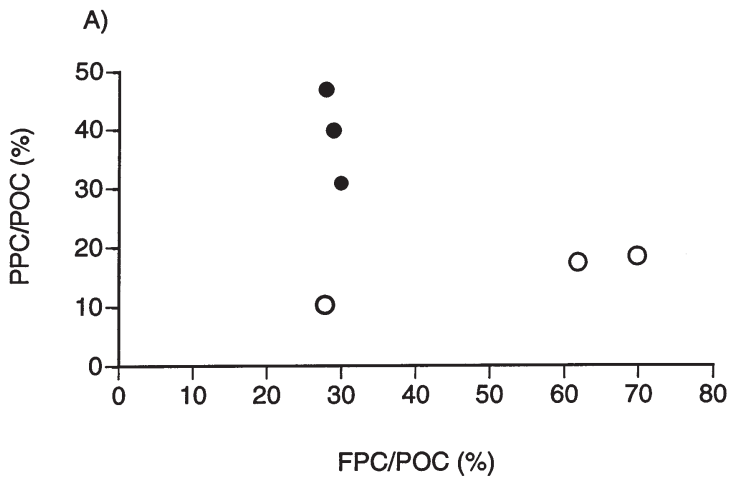

B)

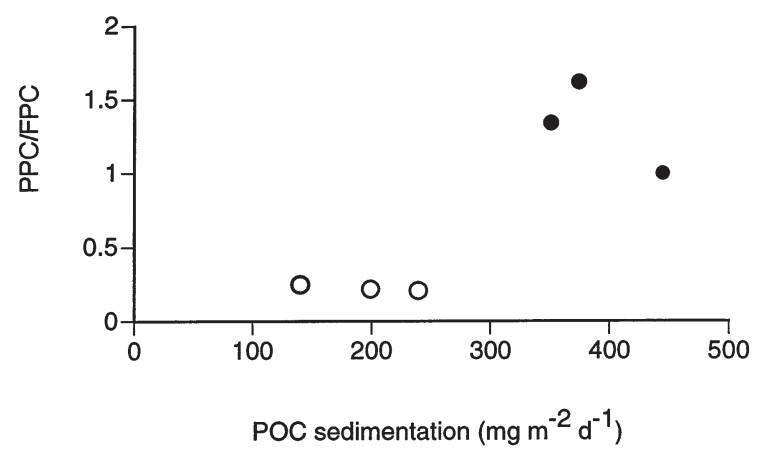

Fig. 9. (A) Relationship between the average FPC to POC ratio (\%) and $\mathrm{PPC}$ to $\mathrm{POC}$ ratio (\%) at $60 \mathrm{~m}$ depth in 3 fjords and 5 years during April. (B) Relationship between the PPC/FPC ratio and the POC sedimentation $\left(\mathrm{mg} \mathrm{C} \mathrm{m}^{-2} \mathrm{~d}^{-1}\right)$. Data from Table 1. (O) Balsfjord 1982, 1992 and 1996; $(\bullet)$ present investigation
Smith et al. 1991, Wassmann 1994). Previously, minimal vertical $P$. pouchetii carbon export to depths $>60 \mathrm{~m}$ was reported in Balsfjord when the preservative formaldehyde, which does not preserve flagellates and mucilaginous matter well, was used (Lutter et al. 1989, Riebesell et al. 1995). With an improved preservation method (Rousseau et al. 1990), we were able to examine the degree to which diatoms and P. pouchetii single and colonial cells contributed to vertical export in northern Norwegian fjords.

In April 1997, the integrated average carbon concentration in the upper $40 \mathrm{~m}$ was 1450, 825 and $920 \mathrm{mg} \mathrm{C}$ $\mathrm{m}^{-2}$ for diatoms and 24, 82 and $610 \mathrm{mg} \mathrm{C} \mathrm{m}^{-2}$ for Phaeocystis pouchetii in Balsfjord, Malangen and Ullsfjord, respectively (T. R. \& M.R., unpubl. results). This shows that the vernal bloom in 1997 was dominated by diatoms, in particular for Balsfjord and Malangen. At the start of the investigation, the nutrient concentrations for silicate and nitrate were $2.8,1.7$, and $1.7 \mu \mathrm{M}$ and $5.3,4.0$, and $2.9 \mu \mathrm{M}$ in the surface layer in Balsfjord, Malangen and Ullsfjord, respectively (J. Stefels unpubl. results), indicating that some nutrients were already consumed at the start of the investigation. Until the storm in mid-April (which caused an upwelling of nutrient-rich water), the ambient concentrations declined to $0.7,0.3$, and $0.8 \mu \mathrm{M}$ silicate and 1.7, 0.1 , and $0.1 \mu \mathrm{M}$ nitrate in Balsfjord, Malangen and Ullsfjord, respectively. The dissimilarity in composition of phytoplankton taxa and nutrient consumption between fjords suggests differences in the timing of the vernal bloom. Silicate rapidly became limiting for the diatom-dominated vernal bloom in 1997, in contrast to the $P$. pouchetii dominated bloom in 1996 (Wassmann et al. in press). However, there were appreciable quantities of nitrate left in Balsfjord in 1997. The phytoplankton species composition, succession, the time variation and the ambient nutrients in Balsfjord suggest a delay of the vernal bloom compared to Ullsfjord and Malangen.

The increasing sedimentation of diatoms in Balsfjord was dominated by vegetative cells until late April when Chaetoceros socialis spores became dominant. In Malangen, the diatom sedimentation rates were lower, and $C$. socialis resting spores were more important than vegetative cells, even in the deepest traps. Ullsfjord seemed to be in an intermediate position, with a higher vertical flux of diatoms, a higher contribution from vegetative cells compared to Malangen, and a maximum in the flux of $C$. socialis spores in midApril. The appearance of resting spores, which was observed from April 12 onwards and especially towards the end of the investigation, suggests silicate limitation (Pitcher 1986, Rey \& Skjoldal 1986) and the end of the diatom bloom (Smetacek 1985). The proportion of diatom and Phaeocystis pouchetii carbon during 
the bloom was also reflected in the average vertical export at $40 \mathrm{~m}$ with 130,90 and $115 \mathrm{mg} \mathrm{C} \mathrm{m}^{-2} \mathrm{~d}^{-1}$ (diatoms) and 2, 13 and $60 \mathrm{mg} \mathrm{C} \mathrm{m}^{-2} \mathrm{~d}^{-1}$ (P. pouchetii) in Balsfjord, Malangen and Ullsfjord, respectively (Fig. 7). This implies that on average, about $10 \%$ of the standing stock of both diatom and $P$. pouchetii carbon sank through the $40 \mathrm{~m}$ horizon per day, suggesting that the relative daily vertical loss rates for both taxa were similar.

In contrast to 1997, Phaeocystis pouchetii dominated the vernal bloom in Balsfjord in 1996. The respective average standing stock of diatom and $P$. pouchetii carbon was 417 and $1120 \mathrm{mg} \mathrm{C} \mathrm{m}^{-2}$ in the upper $40 \mathrm{~m}$, respectively, while the equivalent average vertical export at $40 \mathrm{~m}$ was 19 and $60 \mathrm{mg} \mathrm{C} \mathrm{m}^{-2} \mathrm{~d}^{-1}$ (M.R. et al. unpubl.). This implies average daily vertical loss rates at $40 \mathrm{~m}$ depth of approximately $5 \%$, again for both taxa. The relative vertical biogenic matter loss in April 1997 was far greater compared with that of the previous year. Once again, one could speculate that a higher abundance of large zooplankton in 1996 may explain the relatively low loss of suspended PPC in 1996 and the relatively high loss of suspended PPC in 1997. This suggestion is consistent with the findings that the average mesozooplankton standing stock (0$170 \mathrm{~m})$ in Balsfjord was about $880 \mathrm{mg} \mathrm{C} \mathrm{m}^{-2}$ in April 1996 and only $300 \mathrm{mg} \mathrm{C} \mathrm{m}^{-2}$ in April 1997 (Pasternak et al. in press, E.A. unpubl. results, Wexels Riser et al. unpubl.). A match scenario, strongly controlled by grazers, was observed on the adjacent northern Norwegian shelf in 1994. The suspended biomass and vertical export of larger phytoplankton species were insignificant due to the presence of advected mesozooplankton stock of $>2000 \mathrm{mg} \mathrm{C} \mathrm{m}^{-2}$ (Andreassen et al. 1999, Ratkova et al. 1999).

TEP is assumed to be an important category of particles which induce aggregation, in particular among diatoms (Alldredge et al. 1993, Passow et al. 1994). However, the present investigation does not support the view that suspended (data not shown) or sedimented TEP is connected to diatom abundance. The vertical TEP flux was low, in direct contrast to the significance of diatoms in vertical export, but highest in Ullsfjord, intermediate in Malangen and lowest in Balsfjord. TEP does not belong to a type of organic particles that are universally present during diatom blooms. Our data rather suggest that there is a relationship between Phaeocystis pouchetii and TEP sedimentation. Indeed, TEP originating from $P$. pouchetii has been reported as large in size and produced by decaying colonies (Passow \& Wassmann 1994, M.R. et al. unpubl.). We therefore suggest that TEP is derived from decaying $P$. pouchetii colonies and that they contribute to aggregate formation and general export of particulate matter.
Compared to the vertical export of diatom carbon, the signal from Phaeocystis pouchetii decreased more strongly below $40 \mathrm{~m}$ depth. On average, diatom and $P$. pouchetii cell carbon decreased with depth by a factor of 1.9 and 2.6 between 40 and $100 \mathrm{~m}$ in 1997, respectively. A comparison of the $P$. pouchetii sedimentation during the different investigations has to take into account the preservatives used. A glutaraldehydeLugol cocktail was applied in Balsfjord in 1996, and the data are thus comparable with the present investigation. However, the decrease in flux with depth for $P$. pouchetii was smaller in 1996 and 1997 than that reported by Riebesell et al. (1995), using formaldehyde. It is suggested that the application of the preservative formaldehyde in long-term deployed traps, as well as under storage prior to microscopic analysis, was the reason for the scarcity of $P$. pouchetii cells prior to the investigations in 1996 and 1997. Although the vertical export of $P$. pouchetii cells decreases more rapidly than that of diatoms due to dissolution, viral lysis and cell abandonment of colonies (Boekel et al. 1992, Passow \& Wassmann 1994, Bratbak et al. 1998), most likely the $P$. pouchetii carbon export has previously been underestimated (e.g. Andreassen \& Wassmann 1998).

\section{Differences in vertical flux between fjords and interannual variations}

A summary of the export of POC, PPC, FPC and detritus in the 3 fjords reveals that the differences between the fjords, although significant with regard to variations in timing (Figs. 3, 6 \& 8), were small on average in April 1997. Variations in the vertical export of POC, PPC and FPC at $60 \mathrm{~m}$ depth ranged only between 13 and $15 \%$ (Table 1), while that of detritus was moderately higher (34\%). Based on environmental differences with regard to access to the shelf, the similarity in vertical export of biogenic matter is surprising. The hypothesis that interannual differences in vertical export of biogenic matter are more substantial than the differences between the fjords is strongly supported by the data given in Table 1. While vertical export of POC, PPC and FPC in the 3 fjords varied within 13 to $15 \%$ in April 1997, the equivalent variations in Balsfjord for April 1982, 1992, 1996 and 1997 were 38, 110 and 50\% for all POC, PPC and FPC, respectively. The interannual variability for vertical PPC export appears to be particularly large. While the variability for the entire data set was only $53 \%$ for POC, that of PPC was $88 \%$, with FPC varying about $68 \%$ (Table 1). For the detrital fraction, the relative contribution to vertical POC export was also quite variable (Table 1), but these estimates are more difficult to interpret as they are derived 
by simple difference. Also, broken faecal pellets, which could not be positively identified under the microscope, appeared as a part of the detrital fraction and, depending on the intensity of vertical flux mediation by zooplankton (e.g. coprorhexy etc.), a major part of the detrital pool may have been of faecal pellet origin.

The limited information regarding the interannual variation of vertical PPC and FPC export in the northern Norwegian fjords suggests that significant interannual differences may be induced by differences in the grazing of zooplankton. This is reflected in the relationship of the FPC/POC and PPC/POC flux ratios (Fig. 9). For Balsfjord, except for the year 1997, there appears to be a linear relationship between vertical FPC and PPC export (Fig. 9), which has a low angle, indicating that FPC export is relatively high, while PPC export is relatively low. Obviously, the grazing of zooplankton (preventing PPC from sinking and producing faecal pellets) is important in the composition of vertical export. The results from 1997 are conspicuously different (Fig. 9) from those of previous years with far greater vertical export of PPC, while FPC export remains moderately high. In 1997, the zooplankton community in the fjords was apparently unable to prevent the vertical loss of ungrazed phytoplankton, suggesting that they may play a key role in defining the composition of vertical export of biogenic matter in northern Norwegian fjords. Unfortunately, a test of this suggestion is not possible because simultaneous investigations of zooplankton were only carried out in Balsfjord in 1996 (Pasternak et al. in press., Wexels Riser et al. unpubl.) and during the present investigation in 1997 (E. Arashkevich unpubl. results). Since zooplankton occupies a keystone role for the carbon flux, steps have to be taken to intensify zooplankton investigations in the area.

\section{CONCLUSIONS}

The annual magnitude and biogenic composition of vertical export are similar in different fjords, but interannual differences are great.

The timing of the vernal bloom and its export can vary between different fjords.

Faecal pellets dominated the vertical export during spring in most years, but not in 1997, when phytoplankton comprised a major fraction of the sinking carbon.

The average daily vertical loss rates for diatoms and Phaeocystis pouchetii from the upper layers are similar during spring blooms, suggesting that vertical export of larger phytoplankton cells is proportional to their standing stock in spring.

Matches between phyto- and zooplankton were observed in 3 out of 4 vernal periods, for which the present investigation represents a mismatch scenario. However, the average daily vertical loss rates for diatoms and Phaeocystis pouchetii from the upper layers were twice as high during mismatch compared to match scenarios.

Meso- and macrozooplankton dynamics in the north Norwegian fjords appear to play a pivotal role for the carbon flux in general and the vertical coupling in particular. Their grazing impact in the fjords depends on the oceanic-coastal coupling through advection of populations.

Acknowledgements. The unconditional and personal support of the crew of RV 'Johan Ruud' during the field campaign is gratefully acknowledged. We are grateful that J. Stefels gave us access to nutrient and suspended POC data. Special thanks to Peter Verity for constructive support and bold handling of never-ending numbers of water bottles in daily snowstorms at 5:00 $\mathrm{h}$ in a historic month when the snow record in Tromsø increased by $50 \mathrm{~cm}$ to $240 \mathrm{~cm}$ ! Frøydis Strand prepared some of the figures. This work is a contribution to the European Union Research Programme 'Preserving the Ecosystem' in the framework of the ESCAPE project carried out under contract MAS3-CT96-0050. This is contribution ELOISE no. 129. M.R was funded by the Norwegian Research Council (NFR) through the programme MAREMI.

\section{LITERATURE CITED}

Aksnes DL, Aure J, Kaartvedt S, Magnesen T, Richard J (1989) Significance of advection for the carrying capacities of fjord populations. Mar Ecol Prog Ser 50:263-274

Alldredge AL, Passow U, Logan BE (1993) The abundance and significance of a class of large, transparent organic particles in the ocean. Deep-Sea Res 40:1131-1140 
Andreassen IJ, Wassmann P (1998) Vertical flux of phytoplankton and particulate biogenic matter in the marginal ice zone of the Barents Sea in May 1993. Mar Ecol Prog Ser 140:1-14

Andreassen IJ, Wassmann P, Ratkova T (1999) Seasonal variation of vertical flux of phytoplankton and biomass on the north Norwegian shelf break. Sarsia 84:227-238

Braarud T (1975) The natural history of the Hardangerfjord. 12. The late summer water exchange and phosphate distribution, and the introduction of an offshore population into the fjord in June, 1956. Sarsia 58:9-30

Bratbak G, Jakobsen A, Heldal M, Nagasaki K, Thingstad F (1998) Virus production in Phaeocystis pouchetii and its relation to host cell growth and nutrition. Aquat Microb Ecol 16(1):1-9

Cushing DH (1975) Marine ecology and fisheries. Cambridge University Press, Cambridge

Cushing DH (1990) Plankton production and year-class strength in fish populations: an update of the match/mismatch hypothesis. Adv Mar Biol 26:249-293

Edler L (ed) (1979) Recommendations for marine biological studies in the Baltic Sea - phytoplankton and chlorophyll. The Baltic Marine Biologists Publ 5:1-38

Eilertsen HC (1993) Spring blooms and stratification. Nature 363:24

Eilertsen HC, Sandberg S, Tøllefsen H (1995) Photoperiodic control of diatom spore growth: a theory to explain the onset of phytoplankton blooms. Mar Ecol Prog Ser 116: 303-307

Erga SR, Heimdal BR (1984) Ecological studies of the phytoplankton of Korsfjorden, western Norway. The dynamics of a spring bloom seen in relation to hydrographic conditions and light regime. J Plankton Res 6:67-90

Falkenhaug T, Nordby E, Svendsen H, Tande KS (1995) Impact of advective processes on displacement of zooplankton biomass in north Norwegian fjord system: a comparison between spring and autumn. In: Skjoldal HR, Hopkins C, Erikstad KE, Leinaas HP (eds) Ecology of fjords and coastal waters. Elsevier Science, Amsterdam, p 195-217

Fransz HG, Gieskes WWC (1984) The unbalance of phytoplankton and copepods in the North Sea. Rapp PV Reun Cons Int Explor Mer 183:218-225

Hegseth E, Svendsen H, von Quillfeldt CH (1995) Phytoplankton in fjords and coastal waters of northern Norway: environmental conditions and dynamics of the spring bloom. In: Skjoldal HR, Hopkins C, Erikstad KE, Leinaas HP (eds) Ecology of fjords and coastal waters. Elsevier Science, Amsterdam, p 45-72

Heiskanen AS (1998) Factors governing sedimentation and pelagic nutrient cycles in the Northern Baltic Sea. Monogr Boreal Environ Res, Vol 8

Heiskanen AS, Kononen KJ (1994) Sedimentation of vernal and late summer phytoplankton communities in the coastal Baltic Sea. Arch Hydrobiol 131:175-198

Holm-Hansen O, Lorenzen CJ, Holmes RW, Strickland JDH (1965) Fluorometric determination of chlorophyll. J Cons Perm Int Explor Mer 30:3-15

Kiørboe T, Lundsgaard C, Olesen M, Hansen JL (1994) Aggregation and sedimentation processes during a spring phytoplankton bloom: a field experiment to test coagulation theory. J Mar Res 52:297-323

Laws EA, Bienfang PK, Ziemann AD, Conquest LD (1988) Phytoplankton population dynamics and the fate of production during the spring bloom in Auke Bay, Alaska. Limnol Oceanogr 33:57-65

Lutter S, Taasen JP, Hopkins CCE, Smetacek V (1989) Phyto- plankton dynamics and sedimentation processes during spring and summer in Balsfjord, northern Norway. Polar Biol 10:113-124

Passow U, Alldredge A (1995) A dye-binding assay for the spectrophotometric measurement of transparent exopolymer particles (TEP). Limnol Oceanogr 40:1326-1335

Passow U, Wassmann P (1994) On the trophic fate of Phaeocystis pouchetii (Hariot). IV. Aggregation of P. pouchetii colonies. Mar Ecol Prog Ser 104:153-161

Passow U, Alldredge A, Logan B (1994) The role of particulate carbohydrate exudates in the flocculation of diatom blooms. Deep-Sea Res 41:335-357

Pasternak A, Arashkevich E, Wexels Riser C, Ratkova T, Wassmann P (in press) Seasonal variation in zooplankton and suspended faecal pellets in the subarctic fjord Balsfjorden, northern Norway, in 1996. Sarsia

Peinert R (1986) Production, grazing and sedimentation in the Norwegian Coastal current. In: Skreslet S (ed) The role of freshwater: outflow in coastal marine ecosystems. Springer-Verlag, Berlin, p 361-374

Pitcher GC (1986) Sedimentary flux and the formation of resting spores of selected Chaetoceros species at two sites in the southern Benguela system. S Afr J Mar Sci 4:231-244

Ratkova TN, Wassmann P, Verity PG, Andreassen IJ (1999) Abundance and biomass of pico-, nano- and microplankton along a transect on Nordvestbanken, north Norwegian shelf, in 1994. Sarsia 84:213-225

Reigstad M, Wassmann P (1996) The importance of advection for the pelagic-benthic coupling in north Norwegian fjords. Sarsia 80:245-257

Rey F, Skjoldal HR (1986) Consumption of silicic acid below the euphotic zone by sedimenting diatom blooms in the Barents Sea. Mar Ecol Prog Ser 36:307-312

Riebesell U, Reigstad M, Wassmann P, Passow U, Noji T (1995) On the trophic fate of Phaeocystis pouchetii. VI. Significance of Phaeocystis-derived mucus for vertical flux. Neth J Sea Res 33:193-203

Rousseau V, Mathot S, Lancelot C (1990) Calculating carbon biomass of Phaeocystis sp. from microscopic observations. Mar Biol 107:305-314

Semina H (1978) Treatment of an aliquot sample. In: Sournia A (ed) Phytoplankton manual. UNESCO, Paris, p 181

Smayda T (1978) From phytoplankton to biovolume. In: Sournia A (eds) Phytoplankton manual. UNESCO, Paris, p 273-279

Smetacek V (1985) Role of sinking in diatom life-history cycles: ecological, evolutionary and geological significance. Mar Biol 84:239-251

Smetacek V, von Bodungen B, Knoppers B, Peinert R, Pollehne F, Stegmann P, Zeitzschel B (1984) Seasonal stages characterising the annual cycle of an inshore pelagic system. Rapp PV Cons Int Explor Mer 183:126-135

Smith WO, Codispoti LA, Nelson DM, Manley T, Buskey EJ, Niebauer HJ, Cota GF (1991) Importance of Phaeocystis blooms in the high-latitude ocean carbon cycle. Nature 35: 514-516

Strathmann (1967) Estimating the organic carbon content of phytoplankton from cell volume or plasma volume. Limnol Oceanogr 12:411-418

Svendsen H (1995) Physical oceanography of coupled fjordcoast systems in northern Norway with special focus on frontal dynamics and tides. In: Skjoldal HR, Hopkins C, Erikstad KE, Leinaas HP (eds) Ecology of fjords and coastal waters. Elsevier Science, Amsterdam, p 149-164

van Boekel WHM, Hansen FC, Riegman R, Bak RPM (1992) Lysis-induced decline of a Phaeocystis spring bloom and coupling with the microbial food web. Mar Ecol Prog Ser 81:269-276 
Verity PG, Wassmann P, Ratkova TN, Andreassen IJ, Nordby E (1999) Seasonal patterns in composition and biomass of autotrophic and heterotrophic nano- and microplankton communities on the north Norwegian shelf. Sarsia 84:265-277

Wassmann P (1991) Dynamics of primary production and sedimentation in shallow fjords and polls of western Norway. Oceanogr Mar Biol Annu Rev 29:87-154

Wassmann P (1994) Significance of sedimentation for the termination of Phaeocystis blooms. J Mar Syst 5:81-100

Wassmann P (1998) Retention versus export food chains: pro-

Editorial responsibility: Otto Kinne (Editor),

Oldendorf/Luhe, Germany cesses controlling sinking loss from marine pelagic systems. Hydrobiologia 363:29-57

Wassmann P, Svendsen H, Keck A, Reigstad M (1996) Selected aspects of the physical oceanography and particle fluxes in fjords of northern Norway. J Mar Syst 8:53-71

Wassmann P, Reigstad M, Øygarden S, Rey F (in press) Seasonal variation in hydrography, nutrients, and suspended biomass in a sub-arctic fjord: applying hydrographic features and biological markers to trace water masses and circulation significant for phytoplankton production. Sarsia

Submitted: November 23, 1999; Accepted: March 24, 2000

Proofs received from author(s): July 7, 2000 